\title{
Pengaruh Sosial Budaya, Kelompok Rujukan dan Komunikasi Pemasaran Terhadap Keputusan Mahasiswa Dalam Memilih Program Studi di Perguruan Tinggi
}

\author{
Ibrahim Hafid \\ Dosen Kopertis Wilayah IX Sulawesi
}

\begin{abstract}
Abstrak: Penelitian ini bertujuan untuk menganalisis dan mengetahui pengaruh: 1) sosial budaya terhadap faktor pribadi, motivasi dan pengambilan keputusan mahasiswa dalam memilih program studi di perguruan tinggi; 2) kelompok rujukan terhadap motivasi, faktor pribadi dan pengambilan keputusan; 3) komunikasi pemasaran dalam pengambilan keputusan; 4) faktor pribadi, terhadap motivasi dan pengambilan keputusan; 5) motivasi, pengambilan keputusan mahasiswa dalam memilih program studi di perguruan tinggi. Penelitian ini menggunakan metode survei dengan jumlah sampel 262 responden, dianalisis dengan menggunakan model Structural Equation Modeling (SEM), serta penentuan sampel berdasarkan metode multiple satege sampling. Hasil penelitian menunjukkan bahwa: 1) lingkungan sosial budaya berpengaruh positif dan signifikan terhadap faktor pribadi,motivasi dan pengambilan keputusan dalam memilih program studi; 2) kelompok rujukan berpengaruh positif dan signifikan terhadap faktor pribadi,motivasi, dan pengambilan keputusan; 3) komunikasi pemasaran berpengaruh positif dan signifikan terhadap pengambilan keputusan; 4) faktor pribadi berpengaruh positif dan signifikan terhadap motivasi, namun tidak-signifikan terhadap pengambilan keputusan; 5) motivasi berpengaruh positif dan signifikan terhadap pengambilan keputusan mahasiswa dalam memilih program studi di perguruan tinggi.
\end{abstract}

Kata kunci: sosial budaya, kelompok rujukan, komunikasi pemasaran, faktor pribadi, motivasi dan pengambilan keputusan

\begin{abstract}
The aims of this research are: 1 ) to analyze the effect of social and culture to personal factor, the motivation and decision making; 2 ) to analyze the effect of reference group to motivation, personal factor and decision making; 3 ) to analyze the effect of marketing communication to decision making; 4) to analyze the effect of personal factor to motivation and decision making; and 5) to analyze the effect of motivation to students' decision making in choosing field of studies at higher education. This research using the survey method with the amount of sample 262 respondents, it is analyzed using Structural Equation Modeling (SEM) and the determination of sample pursuant to Multiple Stage Sampling method. This research shows that: 1) Social and cultural environment give positive and significant effect to personal factor, motivation and decision making but insignificant to perception and attitude formation; 2) Reference group gives positive and significant effect to personal factor, motivation and decision making; 3) Marketing communication gives positive and significant effect in decision making; 4) Personal factor gives positive and significant effect to motivation, but insignificant to decision making; and 5) The motivation gives positive and significant effect to decision making of students in choosing field of studies in higher education.
\end{abstract}

Key words: social culture, reference group, marketing communication, personal factor, motivation and decision making.

\section{Pendahuluan}

Salah satu penyebab mengapa masyarakat di Amerika Utara, Eropa Barat, Jepang, beberapa negara penghasil minyak di Timur Tengah dan beberapa negara yang sedang berkembang menjadi negara industri, seluruhnya mencerminkan hanya kurang lebih $16 \%$ penduduk dunia, meng- hasilkan kurang lebih 58\% PDB dunia adalah ternyata masyarakat tersebut dalam pembangunan bangsanya telah dapat berhasil mengandalkan pada keunggulan sumberdaya manusia terbarukan (Habibie, 2004).

Sejalan dengan pandangan Schuler dan Jackson (1990), mengatakan bahwa perkem- 
bangan pada beberapa sektor yang diyakini sebagai 7 kunci industri dalam sepuluh tahun mendatang yang meliputi: microelektronika, bioteknologi, industri bahan baku, penerbangan sipil, telekomunikasi, robot dan peralatan mesin serta computer dan software, semuanya merupakan industri yang berbasis brainpower. Fakta empiris tersebut menunjukkan bahwa dalam perspektif jangka panjang sebuah negara jika ingin meningkatkan kesejahteraan rakyatnya tidak memiliki pilihan lain kecuali harus membangun kapasitas sumberdaya manusianya. Beberapa pandangan di atas membuktikan bahwa keberadaan sumberdaya manusia, baik secara mikro maupun secara makro memiliki peran yang sangat strategis. Hampir semua negara di belahan dunia ini menyakini bahwa sektor pendidikan memegang peran penting dalam pembangunan bangsanya (Nandika, 2006).

Jalur pendidikan termasuk pendidikan tinggi merupakan jenjang pendidikan setelah pendidikan menengah yang mencakup program pendidikan diploma, sarjana, magister, spesiialis, dan doktor yang diselenggarakan oleh pendidikan tinggi (UU Sisdiknas No. 20 Tahun 2003), bertujuan untuk menyiapkan peserta didik menjadi anggota masyarakat yang memiliki kemampuan akademik dan/atau professional yang dapat menerapkan, mengembangkan dan/atau memperkaya khasanah ilmu pengetahuan, teknologi dan/atau kesenian (PP Nomor 60 Tahun 1999).

Tingkat kompetisi pendidikan di Indonesia ditingkat negara-negara ASEAN, dapat dilihat dari indikator pembangunan Sumberdaya Manusia yang ditunjukkan oleh Human Development Index (HDI). Angka human development index (HDI) menurut versi UNDP, Indonesia menempati urutan ke-7 satu tingkat di bawah Vietnam dengan besaran indeks 0,728 . Indikator di atas menunjukkan rendahnya daya kompetisi Indonesia dalam kancah persaingan global. Daya saing Indonesia dalam World Competitiveness (WC) menempati urutan ke-5, sementara menurut versi Global Competitiveness indeks (GCI) Indonesia menempati urutan ke- 6 di-antara negara ASEAN atau berada di bawah Vietnam.

Pendidikan Tinggi sebagai salah satu komponen dan pelaku utama dalam upaya mencerdaskan kehidupan bangsa mempunyai tanggungjawab dan peran yang sangat strategis untuk mengambil bagian dalam usaha mengatasi permasalahan tersebut, melalui peningkatan mutu dan kompetensi lulusannya. Perubahan paradigma pengelolaan pendidikan tinggi telah bergeser dari pendekatan sentralistik ke arah pendekatan desentralisasi serta terikat pada satu tujuan sebagaimana dirumuskan dalam Visi 2010 Pendidikan Tinggi Indonesia, yaitu pada tahun 2010 telah dapat diwujudkan sistem pendidikan tinggi, termasuk perguruan tinggi yang sehat, sehingga mampu memberikan kontribusi pada daya saing bangsa, dengan ciri: berkualitas, memberi akses dan berkeadilan serta otonomi (Dikti, 2004).

Secara kuantitas pertumbuhan sektor pendidikan tinggi mengalami peningkatan yang cukup signifikan. Hal tersebut dapat dilihat dari pertumbuhan jumlah perguruan tinggi, khsusunya perguruan tinggi swasta. Sampai tahun 2004 jumlah perguruan tinggi di Indonesia mencapai 2.428 perguruan tinggi. Dari jumlah tersebut sejumlah $81(3,33 \%)$ perguruan tinggi negeri (PTN) dan $2347(96,6 \%)$ berstatus sebagai perguruan tinggi swasta (PTS). Jumlah tersebut mengalami peningkatan yang cukup tajam dari jumlah 1.634 Perguruan Tinggi pada tahun 1999 menjadi 2.428 Perguruan Tinggi pada tahun 2004 atau naik sebesar 67,2\%. (Nandika, 2006).

Propinsi Sulawesi Selatan sebagai salah sentra pendidikan di Kawasan Timur Indonesia, memberikan perhatian yang cukup besar dalam pengembangan sektor pendidikan, mulai dari tingkat pendidikan dasar sampai pada pendidikan tinggi. Sampai tahun 2007 jumlah perguruan tiggi di Sulawesi Selatan mencapai 311, yang terdiri dari 3 perguruan tinggi negeri (PTN), 2 politeknik negeri serta 306 perguruan tinggi swasta (PTS) serta membina kurang lebih 1.141 program studi dari berbagai jenjang studi. Sejalan dengan itu jumlah calon mahasiswa baru yang mendaftar diberbagai perguruan tinggi, baik negeri maupun swasta diseluruh Indonesia setiap tahunnya diperkirakan mencapai 400.000 orang dengan berbagai pilihan progran studi dan jenjang pendidikan (Sarjana dan Diploma).

Data calon mahasiswa baru yang mendaftar melalui sistem penerimaan mahasiswa baru (SPMB) tahun 2007 pada 37 panitia lokal dan 57 
Perguruan Tinggi Negeri di seluruh indonesia mencapai 393.168 orang peserta. Jumlah tersebut mengalami peningkatan dari tahun 2006 sebesar $14 \%$. Dari jumlah pendaftar tersebut diperkirakan yang akan diterima kurang lebih 85.000 orang atau kurang lebih $25 \%$. Sisanya sebesar $75 \%$ diperkirakan akan mamasuki perguruan tinggi swasta dengan berbagai pilihan program studi.

Peningkatan minat lulusan SMU untuk melanjutnya pendidikan pada perguruan tinggi merupakan suatu indikasi meningkatnya kesadaran masyarakat tentang pendidikan, khususnya pendidikan tinggi. Selain itu berbagai tuntutan kebutuhan yang semakin kompleks, baik kebutuhan ekonomi maupun sosial diduga merupakan faktor pendorong utama meningkatnya minat masyarakat untuk melanjutkan studi pada jenjang pendidikan tinggi. Salah satu permasalahan yang terjadi dalam proses rekruitmen mahasiswa baru pada perguruan tinggi, adalah adanya kesenjangan yang cukup signifikan terhadap jumlah pendaftar pada beberapa program studi tertentu. Beberapa program studi yang dianggap pavorit memiliki jumlah pendaftar yang cukup besar, namun beberapa program studi lainnya justru perdaftarnya sangat kurang yang pada gilirannya akan berimplikasi pada kualitas proses rekruitmen calon mahasaiswa baru.

Data pendaftar peserta SPMB Tahun 20072008 pada 3(tiga) perguruan tinggi negeri yang dipilih sebagai sebagai sampel, yaitu UNHAS, UNM dan UIN Alauddin diketahui bahwa hanya 24 Program Studi (41\%) di Universitas Hasanuddin yang dapat dikategorikan memiliki peminat cukup besar, sedangkan sisanya 59 program studi (59\%) dapat dikategorikan kurang diminati. Demikian pula pendaftar SPMB di Universitas Negeri Makassar (UNM), hanya 20 program studi (51\%) dikategorikan memiliki peminat cukup besar, sedangkan sisanya 19 program studi (49\%) dapat dikategorikan kurang diminati. Begitu pula pendaftar SPMB di Universitas Islam Negeri Alauddin hanya 15 program studi (37\%) memiliki jumlah pendaftar yang relatif lebih banyak, sedangkan 26 program studi (63\%) jumlah pendaftarnya tidak sampai 100 orang. Data tersebut di atas memberikan gambaran bahwa dari sekian banyak program studi yang ditawarkan pada beberapa perguruan tinggi yang dipilih sebagai sampel, menunjukkan bahwa terdapat sebagian kecil program studi yang memiliki jumlah pendaftar yang cukup besar. Beberapa program studi lainnya memiliki pendaftar yang dapat dikategorikan relatif kurang diminati.

Mengantisipasi penurunan jumlah pendaftar pada beberapa program studi tertentu di perguruan tinggi serta semakin ketatnya tingkat persaingan dalam pengelolaan pelayanan jasa pendidikan, maka satuan pendidikan, khsusunya pengelola program studi harus lebih proaktif dan melakukan berbagai terobosan dalam manajemen pengelolaan program studi. Salah satu pendekatan yang dapat dilakukan untuk memecahan permasalahan yang dihadapi oleh pengelola program studi adalah menggunakan pendekatan perilaku konsumen (Consumer Behavior) sebagai salah satu bagian dari studi pemasaran yang yang secara khusus mempelajari bagaimana cara individu, kelompok dan organisasi memilih, membeli, memakai serta memanfaatkan barang, jasa, gagasan atau pengalaman dalam rangka memuaskan kebutuhan dan hasratnya, termasuk pengambilan keputusan mahasiswa memilih program studi di perguruan tinggi.

Berdasarkan uraian dalam latar belakang penelitian, maka dirumuskan beberapa permasalahan sebagai berikut: 1) Bagaimana pengaruh sosial budaya terhadap motivasi dan pengambilan keputusan mahasiswa dalam memilih program studi di perguruan tinggi? 2) Bagaimana pengaruh kelompok rujukan terhadap motivasi dan pengambilan keputusan mahasiswa dalam memilih program studi di perguruan tinggi? 3) Bagaimana pengaruh komunikasi pemasaran terhadap pengambilan keputusan mahasiswa dalam memilih program studi di perguruan tinggi? 4) Bagaimana pengaruh faktor pribadi terhadap pengambilan keputusan mahasiswa dalam memilih program studi di perguruan tinggi? 5) Bagaimana pengaruh motivasi terhadap pengambilan keputusan mahasiswa dalam memilih program studi di perguruan tinggi?

Mengacu pada uraian pada latar belakang serta pokok permasalahan, tujuan yang ingin dicapai dalam penelitian ini yaitu untuk menganalisis pengaruh: 1) sosial-budaya terhadap motivasi, dan pengambilan keputusan mahasiswa dalam memilih program studi di perguruan tinggi; 
2) kelompok rujukan terhadap motivasi, dan pengambilan keputusan mahasiswa dalam memilih program studi di perguruan tinggi; 3 ) komunikasi pemasaran terhadap pengambilan keputusan mahasiswa dalam memilih program studi di perguruan tinggi; 4) faktor pribadi terhadap pengambilan keputusan mahasiswa dalam memilih program studi di perguruan tinggi; dan 5) motivasi terhadap pengambilan keputusan mahasiswa dalam memilih program studi di perguruan tinggi.

\section{Kajian Literatur Dimensi sosial-budaya dalam perilaku konsumen}

Aspek sosial-budaya merupakan salah satu dimensi kajian yang menarik dalam perilaku konsumen, terutama yang berhubungan dengan bagaimana konsep-konsep sosial-budaya dalam mempengaruhi sikaf dan perilaku konsumen. Menurut Engle, Blackwell dan Miniard (1995), setidaknya terdapat tiga alasan pentingnya mempelajari pengaruh budaya terhadap perilaku konsumen, yaitu: 1) budaya mempengaruhi struktur konsumsi; 2) budaya mempengaruhi bagaimana individu mengambil keputusan; dan 3) budaya merupakan variabel utama dalam penciptaan dan komunikasi makna di dalam produk.

Menurut Kotler (2005), faktor sosial-budaya terdiri atas: budaya, sub-budaya, kelas sosial, keluarga dan kelompok referen. Selanjutnya, budaya secara luas merupakan makna yang dimiliki bersama oleh sebagian besar masyarakat dalam suatu kelompok sosial (Peter dan Olson, 2000). Pendapat Mangkunegara (2005) tentang budaya didefinisikan sebagai hasil kreatifitas manusia dari satu generasi ke generasi berikutnya yang sangat menentukan bentuk perilaku dalam kehidupannya sebagai anggota masyarakat. Pendapat lainnya, Supranto (2007), budaya adalah keseluruhan yang kompleks meliputi pengetahuan, kepercayaan, seni, hukum, moral, kebiasaan, dan setiap kemampuan yang diperoleh setiap orang sebagai anggota masyarakat.

Schiffman dan Kanuk (2007) mendefinisikan budaya sebagai keseluruhan kepercayaan, nilainilai, dan kebiasaan yang dipelajari yang membantu mengarahkan perilaku konsumen para anggota masyarakat tertentu. Sejalan dengan pendapat Peter dan Olson (2000), bahwa kandungan suatu budaya (content of culture) adalah kepercayaan, sikap, tujuan dan nilai-nilai yang dipegang oleh sebagian besar masyarakat dalam suatu lingkungan, di samping arti dari perilaku, aturan, kebiasaan, dan norma yang dianut sebagian masyarakat.

Beberapa hasil penelitian yang relevan seperti penelitian yang dilakukan oleh Monga dan John (2007) pada University of Minnesota, menemukan bahwa konsumen dari budaya timur merasakan derajat tingkat kepuasan yang lebih tinggi dibanding dengan konsumen dari budaya barat. Selain itu, konsumen dari budaya timur akan mengevaluasi perluasan merek dengan lebih baik dibanding dengan konsumen dari budaya barat.

Studi Burroughs dan Mick (2004) menggunakan bahwa konteks keunikan untuk membedakan perilaku masyarakat Asia yang diwakili oleh Malaysia dan perilaku masyarakat barat yang diwakili orang Amerika, menemukan bahwa individu yang tinggal dengan budaya barat cenderung mengekspresikan perbedaan diri dari orang lain sehingga membutuhkan suatu penciptaan kreatif. Makin kuat persepsi akan kesamaan kepemilikan dengan orang lain, makin kuat keinginan untuk mencari sesuatu yang berbeda.

Berkaitan dengan budaya timur, individu didorong untuk menghormati, mengikuti norma dan keputusan kelompok serta menciptakan harmoni dalam dalam bersosialisasi. Dalam konteks budaya timur perbedaan antara individu dan kelompok melebur. Pilihan produk bukan merupakan ekspresi diri seseorang, tetapi pilihan dibuat agar dekat dengan kelompok. Individu ingin mencarai suatu konsistensi untuk melakukan kompromi dengan norma kelompok.

Cateora dan Graham dalam Prasetijo dkk (2005), variabel budaya dapat diukur dengan menggunakan lima dimensi, yaitu: 1) Dimensi materialistik: materi atau peralatan teknologi yang digunakan untuk mengupayakan kehidupan (ekonomi), 2) Dimensi Intitusi Sosial: Bagaimana keluarga, pendidikan, media dan struktur politik diadakan dan dioperasikan, 3) Dimensi Hubungan antara manusia dengan alam: sistem keyakinan, agama, norman, kebiasaan dan nilai-nilai, 4) Dimensi estetik: termasuk kesenian tulis dan bentuk (ukir), musik, drama dan tari dan 5) Dimensi 
bahasa: bahasa verbal dan non-verbal yang digunakan.

\section{Peran kelompok rujukan dalam keputusan pembelian}

Kelompok Rujukan melibatkan satu atau lebih orang yang dijadikan sebagai dasar pembanding antara titik referensi dalam membentuk tanggapan afeksi dan kognisi serta menyatakan perilaku sesorang. (Peter dan Olson, 2000). Sedangkan Shiffman dan Kanuk (2007), mengatakan bahwa kelompok rujukan adalah setiap orang atau kelompok yang dianggap sebagai dasar perbandingan (rujukan) bagi seseorang dalam membentuk nilainilai dan sikaf umum atau khusus atau pedoman khusus bagi perilaku.

Kelompok rujukan yang mempengaruhi nilai atau perilaku yang ditentukan secara umum atau luas disebut kelompok rujukan normatif sedangkan kelompok rujukan yang diperlakukan sebagai tolok ukur bagi sikaf atau perilaku yang ditentukan secara khusus atau sempit disebut kelompok rujukan komparatif. Kelompok rujukan ukurannya sangat beragam, mulai dari satu hingga ratusan orang. Selain itu kelompok referensi seseorang dapat kelas sosial, sub-budaya atau bahkan budaya yang sama atau berbeda.

Beberapa hasil penelitian yang relevan seperti penelitian yang dilakukan oleh Bearden dan Etzel dalam (Peter dan Olson, 2000), ditemukan bahwa pengaruh kelompok referensi pada keputusan produk dan merek beragam paling tidak dalam dua dimensi, yaitu dimensi pertama yang berkaitan dengan sejauhmana suatu produk atau merek adalah sesuatu yang dibutuhkan atau benda yang mewah serta dimensi kedua adalah sejauh mana objek yang sedang yang dipertemukan menarik atau dikenal orang lain.

Hasil penelitian yang dilakukan oleh Burns (2006) terhadap faktor yang mempengaruhi siswa dalam memilih perguruan tinggi di Sekolah Pertanian, Makanan dan sumberdaya alam di School University of Missouri Columbia, menemukan bahwa faktor keluarga, anggota keluarga lainnya dan kelompok referen mempunyai pengaruh yang kuat dalam pemilihan perguruan tinggi. Selain itu, tingkat pengetahun orangtua dan ketersediaan keuangan juga mempengaruhi pemilihan perguruan tinggi.
Menurut Smith dan Bers (1989), orang tua merupakan penginisiatif pemula dalam memilih perguruan tinggi, selain pengaruh guru dan teman. Oleh sebab itu, Murphy (1981) berpendapat bahwa orang tua siswa harus dipertimbangkan secara mendasar sebagai suatu pelanggan sebab evaluasi mereka terhadap karakteristik berbagai perguruan tinggi adalah sangat penting dan berdanpak pada pemilihan perguraun tinggi. Menurut Arambewela et.al (2005), kondisi dan situasi keluarga sangat berpengaruh terhadap perilaku pembelian konsumen. Sebagai contoh ketika suatu keluarga mengalami permasalahan yang dapat menyebabkan tekanan atau stress pada anggota keluarga tersebut, sehingga dapat menyebabkan perilaku compulsive buying (Gulshan dan Paul, 2006).

Selanjutnya, Schiffman dan Kanuk (2007) menyatakan bahwa fungsi keluarga yang dapat dihubungkan dengan perilaku konsumen, dapat dikategorikan menjadi empat, yaitu : 1) Economic Well-being, 2) Emotional support, 3) Suitable familty life-style dan 4) Family member socialization.

Hasil penelitian yang dilakukan oleh Childers dan Rao (1992) yang mengukur pengaruh kepuasan pembelian individu kelompok referensi berdasarkan hubungan keluarga dan rekan sebaya serta menentukan variasi pengaruh pada lintas budaya berdasarkan hubungan keluarga dalam keputusan konsumen individu. Hasil yang ditemukan adalah anggota keluarga dan kelompok referensi memberikan pengaruh yang nyata terhadap keputusan pembelian produk dan jasa yang dibeli.

\section{Pengaruh motivasi terhadap keputusan konsumen}

Menurut Kotler (2005), Wells dan Prensky (1996), dan Stanton (1991) pilihan pembelian konsumen dipengaruhi oleh empat faktor psikologi utama, yaitu: motivasi, persefsi, pembelajaran, serta keyakinan dan sikaf. Motivasi dapat digambarkan sebagai tenaga pendorong dalam diri individu yang memaksa mereka untuk bertindak. Tenaga pendorong tersebut dihasilkan yang timbul sebagai akibat dari kebutuhan yang tidak terpenuhi (Schiffman dan Kanuk, 2007). Terkait dengan motivasi, Supranto (2007) menyatakan bahwa motivasi menunjukkan alasan untuk suatu 
perilaku. Motivasi merupakan kekuatan yang enerjik yang menggerakkan perilaku dan memberikan tujuan dan arah perilaku.

Setiap individu baik secara sadar maupun tidak sadar selalu berjuang untuk mengurangi ketegangan melalui perilaku yang mereka harapkan akan memenuhi kebutuhan mereka dan dengan demikian akan membebaskan mereka dari tekanan yang dirasakan. Tujuan tertentu yang dipilih dan pola tindakan yang mereka lakukan untuk mencapai tujuan tersebut merupakan hasil dari pemikiran dan proses belajar individu.

Menurut Engel, et, al (1998) perilaku yang termotivasi diprakarsai oleh pengaktifan kebutuhan atau pengenalan kebutuhan. Kebutuhan atau motif diaktifkan ketika ada ketidak cocokan yang memadai antara keadaan aktual dengan keadaan yang diinginkan. Karena ketidak cocokan itu meningkat, hasilnya adalah pengaktifan suatu kondisi kegairahan yang dipacu sebagai dorongan (drive).

Menurut Babin, et, al (1994) bahwa pengalaman belanja yang memuaskan bagi pelanggan utilitarian adalah pada saat pelanggan mendapatkan produk yang diinginkan. Sedangkan pengalaman berbelanja yang memuaskan bagi pelanggan hedonik adalah kesenangan dan kenikmatan yang diperoleh selama proses belanja berlangsung. Demikian pula pendapat Sheet dan Mittal (2004), yang membedakan motivasi menjadi motivasi rasional dan motivasi emosional. Motivasi rasional adalah pengambilalan keputusan konsumen yang dengan hati-hati mempertimbangkan semua alternatif dan memilih sesuatu yang dapat memberikan kegunaan terbaik. Motivasi emosional adalah adalah pengambilan keputusan yang memiliki tujuan berdasarkan kriteria subjektif, seperti: harga diri, status, gengsi dan lainnya yang sulit diukur.

Suatu motif merupakan konstruk yang mewakili kekuatan dalam (inner force) yang tak terlihat dan memaksa suatu respon perilaku dan memberikan pengaruh khusus terhadap respon. Perilaku konsumen dalam mengkonsumsi suatu produk dapat disebabkan oleh berrbagai dorongan (motif), namun kadang-kadang konsumen tidak mampu atau menyadari alasan mereka membeli sebuah produk. Menurut Hawkings, el, al (1998), kelompok motif yang dapat dipahami oleh konsumen sebagai faktor pendorong untuk membeli disebut "manifest motives", sedangkan kelompok motif yang tidak diketahui atau disadari atau segan untuk mengakuinya disebut "Iaten motives".

Menurut Maslow (1954) dan McCelleland (1961) dalam Hawkins, Best dan Coney (1998), Teori hirarki kebutuhan Maslow didasarkan pada beberapa premis, antara lain: 1) semua manusia memerlukan suatu set motif yang mirip melalui anugrah genetik dan interaksi sosial; 2) beberapa motif lebih mendasar atau kritis dari pada lainnya; 3) motif yang lebih mendasar harus dipenuhi sampai pada tingkat minimum sebelum motif lain mulai dipenuhi; dan 4) ketika motif dasar sudah dapat dipenuhi maka motif selanjutnya akan timbul. Menurut Teori Motivasi McClelland (1961) dinyatakan bahwa terdapat 3 (tiga) kebutuhan dasar yang dapat memotivasi seorang individu untuk berperilaku, yaitu: 1) kebutuhan untuk sukses (needs for achievement), yaitu keinginan manusia untuk mencapai prestasi, reputasi dan karier yang terbaik; 2) kebutuhan afiliasi (needs for affiliations), yaitu kebutuhan manusia untuk membina hubungan dengan sesamanya, menacri teman yang dapat menerimanya, ingin dimiliki oleh orang-orang sekelilingnya dan ingin memiliki orang-orang yang dapat menerimanya; dan 3) kebutuhan kekuasaan (needs for power), yaitu keiningan seseorang untuk dapat mengontrol lingkungannya termasuk mempengaruhi orangorang disekitarnya dengan tujuan agar dapat mempengaruhi, mengarahkan dan mengatur orang lain.

Beberapa hasil penelitian yang relevan seperti penelitian yang dilakukan oleh Tuggaesti (2007), menemukan bahwa terdapat pengaruh yang positif antara motivasi berbelanja terhadap kepuasan berbelanja. Ketiga variabel elemen motivasi berbelanja, yaitu: socialization, diversion dan utilitarian memberi pengaruh terhadap kepuasan berbelanja.

Penelitian Westbrook dan Balck (1985) dalam Jim dan Kim (2001), mengatakan bahwa motivasi sebagai suatu stimuli yang mempengaruhi perilaku memuaskan keinginan internal, sehingga dapat diasumsikan bahwa motivasi spesifik yang mendasari keinginan belanja konsumen dapat diukur dari tingkat kepuasan. 
Menurut Finn dan Louviere (1996) dalam Jim dan Kim (2001), kepuasan konsumen mengenai dimana akan berbelanja didasarkan pada orientasi internal yang dimiliki yaitu motivasi, kebutuhan dan nilai. Selanjutnya dikatakan bahwa motivasi sebagai suatu kekuatan yang mendorong perilaku untuk memuaskan kebutuhan internal, sehingga motivasi berbelanja seseorang dapat didefinisikan sebagai pengarah perilaku yang membawa konsumen ke lokasi berbelanja untuk dipuaskan kebutuhan internalnya.

Penelitian yang dilakukan oleh Jim dan Kim (2001) menyimpulkan bahwa motivasi berebelanja memiliki pengaruh yang signifikan terhadap kepuasan belanja yang merupakan salah satu bagian dari shopping exitement.

\section{Kerangka Konseptual \& Hipotesis}

Faktor eksternal dalam penelitian ini merupakan variable exogenous dan faktor internal merupakan variable endogenous yang secara keseluruhan dapat mempengaruhi proses pengambilan keputusan calon mahasiswa dalam memilih program studi di perguruan tinggi. Untuk menjelaskan hubungan antar variabel tersebut dapat dilihat pada gambar kerangka konseptual berikut.

Berdasarkan kerangka konseptual tersebut di atas maka hubungan fungsional antar variable dapat dituliskan dalam bentuk persamaan fungsi matematis sebagai berikut :

$$
\begin{aligned}
& Y_{1}=f\left(X_{1}, X_{2}\right) \ldots \ldots \ldots \ldots \ldots \\
& Y_{2}=f\left(Y_{1}, X_{1}, X_{2}\right) \ldots \ldots \ldots \ldots \\
& Y_{3}=f\left(Y_{1}, Y_{2}, X_{1}, X_{2}, X_{3}\right) \ldots
\end{aligned}
$$

Di mana :

$X_{1}$ : Sosial-budaya, $X_{2}$ : Kelompok rujukan, $X_{3}$ : Komunikasi pemasaran, $Y_{1}$ : Faktor pribadi, $Y_{2}$ : Motivasi dan $Y_{3}$ : Pengambilan Keputusan

Pola hubungan antar variabel X1, X2, dan X3 dalam kedudukannya sebagai variabel exogenous tehadap variabel endogenous Y1, Y2 merupakan pola hubungan fungsional yang bersifat langsung dan tidak langusng. Pola hubungan antara variabel Y2, Y1 terhadap Y3 atau proses pengambilan keputusan mahasiswa dalam pemilih program studi di perguruan tinggi adalah juga menggunakan pola hubungan fungsional yang bersifat langsung dan tidak langsung, Pola hubungan antar variabel dalam penelitian ini dianalisis dengan dengan menggunakan model Structural Equation Modeling (SEM), sehingga pengaruh masingmasing variabel exogenous terhadap variabel endogenous intervening dan variabel endogenous dependent dapat diketahui baik yang bersifat langsung maupun yang bersifat tidak langsung.

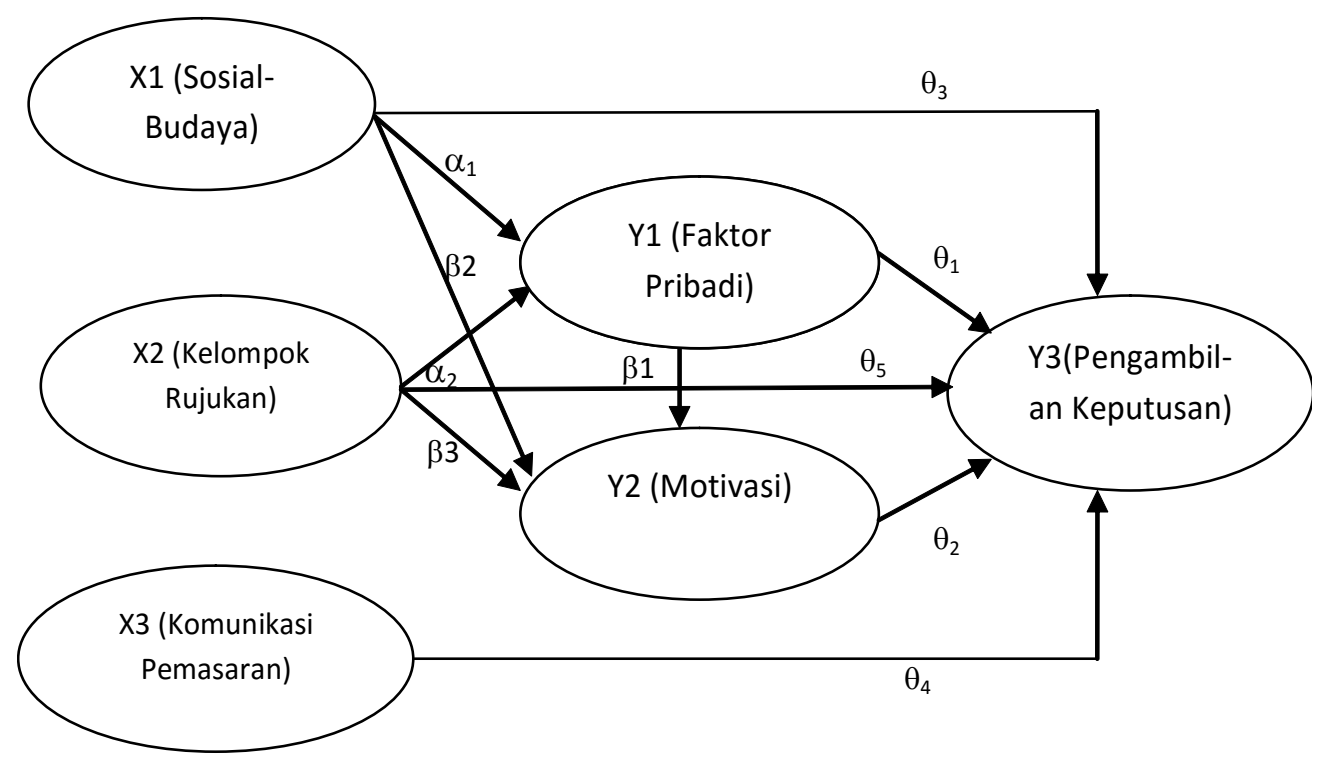

Gambar 1. Kerangka konseptual model pengaruh faktor sosial-budaya (X1), kelompok rujukan (X2), komunikasi pemasaran (X3), Faktor pribadi (Y1), motivasi (Y2) dan pengambilan keputusan (Y3)

Sumber: Hasil rumusan kerangka konseptual, 2008; 
Unit analisis penelitian adalah mahasiswa (pengambilan keputusan), maka variabel sosialbudaya (X1), kelompok rujukan (X2) dan komunikasi pemasaran (X3) merupakan variabel eksogen dengan kata lain perubahan variabel tersebut merupakan bagian eksternal dari sistem, sehingga sangat ditentukan oleh pengaruh dan kondisi lingkungan eksternal masing-masing mahasiswa. Variabel faktor peribadi (Y1) dan motivasi (Y2 merupakan variabel endogenous sebab variabel tersebut sangat tergantung dari lingkungan sosial-budaya, kelompok rujukan yang mempengaruhi calon mahasiswa serta strategi komunikasi pemasaran yang digunakan perguruan tinggi. Dengan kata lain, bahwa faktor pribadi dan motivasi ditentukan oleh pola perubahan ligkungan sosial-budaya, pengaruh kelompok rujukan serta strategi komunikasi pemasaran perguruan tinggi.

Pola hubungan antar variabel seperti dikemukakan pada kerangka konsep dan persamaan 1,2 dan 3 merupakan suatu sistem persamaan simultan yang dapat ditulis dalam bentuk persamaan linier simultan sebagai berikut:

$$
\begin{aligned}
& \mathrm{Y} 1=\alpha 0+\alpha 1 \times 1+\alpha 2 \times 2 \ldots \ldots \ldots \ldots \ldots \ldots \ldots . . \quad(1 \mathrm{a}) \\
& \mathrm{Y} 2=\beta 0+\beta 1 \mathrm{Y} 1+\beta 2 \mathrm{X} 1+\beta 3 \mathrm{X} 2 \ldots \ldots \ldots \ldots . . \\
& \mathrm{Y} 3=\theta 0+\theta 1 \mathrm{Y} 1+\theta 2 \mathrm{Y} 2+\theta 3 \mathrm{X} 1+\theta 4 \mathrm{X} 2+\theta 5 \mathrm{X} 3
\end{aligned}
$$

\section{Hipotesis Penelitian}

Berdasarkan kerangka konseptual yang telah diuraikan dalam paradigma penelitian serta kajian pustaka dan tinjauan penelitian terdahulu, maka dapat dirumuskan hipotesis penelitian sebagai berikut: 1) Sosial budaya berpengaruh positif terhadap faktor pribadi, motivasi dan pengambilan keputusan mahasiswa dalam memilih program studi di perguruan tinggi; 2) Kelompok rujukan berpengaruh positif terhadap faktor pribadi, motivasi dan pengambilan keputusan mahasiswa dalam memilih program studi di perguruan tinggi; 3) Komunikasi pemasaran berpengaruh positif terhadap pengambilan keputusan mahasiswa dalam memilih program studi di perguruan tinggi; 4) Faktor pribadi berpengaruh positif terhadap pengambilan keputusan mahasiswa dalam memilih program studi di perguruan tinggi; dan 5) Motivasi berpengaruh poitif terhadap pengambilan keputusan mahasiswa dalam memilih program studi di perguruan tinggi.

\section{Metodologi Penelitian}

Desain penelitian yang digunakan adalah penelitian explanatory atau confirmation rersearch yang bertujuan untuk menjelaskan hubungan kausal antar variabel melalui pengujian hipotesis dan dilaksanakan dengan pendekatan analisis deskriptif dan verifikatif melalui survei (Rahayu, 2005). Pendekatan analisis yang dugunakan adalah analisis deskriptif dan kausal. Dilihat dari dimensi waktu, maka penelitian ini bersifat cross sectional, yaitu informasi dari sebagian populasi (sample respondent) dikumpulkan langsung ditempat kejadian secara empirik, dengan tujuan untuk mengetahui pendapat dari sebagian populasi terhadap objek yang sedang diteliti (Sekaran, 2003) dan (Malhotra, 1993 ). Adapun metode yang digunakan dalam pelaksanaan penelitian ini adalah metode survei, yaitu metode penelitian yang memanfaatkan kuesioner dalam pengumpulan data utama dalam hal ini adalah data primer sejumlah sampel dari populasi. Selain itu, digunakan juga teknik wawancara secara mendalam (Indepth interview) untuk melengkapi data yang diperlukan (Nazir,2005)

\section{Populasi dan Sampel Penelitian}

Populasi dalam penelitian ini adalah seluruh mahasiswa pada perguruan tinggi (PTN) dan perguruan tinggi swasta (PTS) yang ada di Sulawesi Selatan. Mengingat besarnya jumlah populasi mahasiswa pada perguruan tinggi di Sulawesi Selatan, maka sampel yang dipilih dalam penelitian ini adalah mahasiswa yang memilih beberapa program studi yang masuk dalam kategori program studi pavorit dan program studi yang kurang diminati yang dipilih calon mahasiswa pada perguruan tinggi negeri (PTN) dan beberapa perguruan tinggi swasta (PTS) di Sulawesi Selatan. Adapun responden yang akan menjadi sampel dalam penelitian ini adalah mahasiswa baru angkatan tahun 2007-2008 dengan jumlah sampel 262 orang yang berasal dari 38 program studi. Teknik penarikan sampel dari populasi dalam penelitian ini adalah Multiple Stage Sampling (Nazir, 2005) yaitu sampel yang ditarik dari kelompok pupulasi menjadi anggota sampel, namun hanya sebagian dari anggota sub-populasi menjadi anggota sampel. 


\section{Model dan Teknik Analisis Data}

Model yang digunakan dalam penelitian ini adalah model persamaan struktural atau structural equation modeling (SEM) untuk mengetahui hubungan kausal antar variabel laten yang terdapat dalam persamaan struktural. Untuk menganalisis data hasil survei, menginterpretasi hasil penelitian serta untuk menguji hipotesis, maka digunakan analisis deskriptif, pengujian model pengukuran, pengujian model overal, pengujian model struktural serta pengujian hubungan variabel terobservasi. Untuk memudahkan proses analisis digunakan beberapa program aplikasi statistik, antara lain SPSS (Statistical Package for Service Solution) dan AMOS (Analisis of Momen Structure) yang merupakan paket dalam program SEM (Structural Equation Model). Pengujian model pengukuran dilakukan untuk mengetahhui apakah model pengukuran tersebut compatible atau tidak untuk digunakan. Oleh karena itu, dalam pengujian digunakan metode comfirmatory faktor análisis (CFA) yang terbagi menjadi dua, masing-masing uji goodness of fit dan uji validitas yang selanjutnya dilakukan uji reliabilitas, uji normalitas dan uji outliners.

\section{Hasil Penelitian dan Pembahasan Analisis besarnya pengaruh antar variabel}

Hubungan fungsional antara variabel yang mempengaruhi pengambilan keputusan mahasiswa dalam memilih program studi di perguruan tinggi, terdiri atas tiga variabel exogenuus, masingmasing: sosial-budaya, kelompok rujukan dan komunikasi pemasaran. Sedangkan variabel endogenous terdiri atas faktor pribadi, motivasi, dan pengambilan keputusan. Hasil analisis data dengan menggunakan Structural Equation Modeling (SEM) sebagaimana ditampilkan dalam Tabel-1 memperlihatkan tingkat signifikansi dan besarnya pengaruh masing-masing variabel. Hubungan pengaruh variabel yang digunakan dapat dilihat dari nilai koefisien Standarized Regresión Weight atau nilai probability.

Tabel 1. Hasil estimasi parameter pengaruh langsung antar variabel berdasarkan model SEM

\begin{tabular}{|c|c|c|c|c|c|c|}
\hline No. & $\begin{array}{c}\text { Variabel } \\
\text { berpengaruh }\end{array}$ & Variabel dipengaruhi & $\begin{array}{c}\text { Simb } \\
\text { ol }\end{array}$ & $\begin{array}{c}\text { Nilai } \\
\text { Estimasi }\end{array}$ & $\begin{array}{c}\mathrm{t}- \\
\text { hitung }\end{array}$ & $\mathrm{P}$ \\
\hline 1. & $\begin{array}{c}\text { (X1) } \\
\text { Sosial-budaya }\end{array}$ & $\begin{array}{l}\text { Y1 Faktor pribadi } \\
\text { Y2 Motivasi } \\
\text { Y3Pengambilan keputusan }\end{array}$ & $\begin{array}{l}\alpha_{1} \\
\beta_{2} \\
\theta 3\end{array}$ & $\begin{array}{l}0,453 \\
0,254 \\
0,089\end{array}$ & $\begin{array}{l}11,159 \\
2,411 \\
1,379\end{array}$ & $\begin{array}{l}0,000^{* * *} \\
0,008^{* *} \\
0,084^{*}\end{array}$ \\
\hline 2. & $\begin{array}{c}\text { (X2) } \\
\text { Kelompok Rujukan }\end{array}$ & $\begin{array}{l}\text { Y1 Faktor pribadi } \\
\text { Y2 Motivasi } \\
\text { Y3Pengambilan keputusan }\end{array}$ & $\begin{array}{l}\alpha_{2} \\
\beta_{3} \\
\theta 5\end{array}$ & $\begin{array}{l}0,249 \\
0,197 \\
0,059\end{array}$ & $\begin{array}{l}8,716 \\
3,268 \\
1,368\end{array}$ & $\begin{array}{c}0.000^{* * *} \\
0,001^{* * *} \\
0,086^{*}\end{array}$ \\
\hline 3. & $\begin{array}{c}(\mathrm{X} 3) \\
\text { Komunikasi } \\
\text { pemasaran }\end{array}$ & Y3 Pengambilan keputusan & $\theta 4$ & 0,043 & 3,482 & $0.000^{* * *}$ \\
\hline 4. & $\begin{array}{c}(\mathrm{Y} 1) \\
\text { Faktor pribadi }\end{array}$ & $\begin{array}{l}\text { Y2 Motivasi } \\
\text { Y3 Pengambilan keputusan }\end{array}$ & $\begin{array}{l}\beta_{1} \\
\theta 1\end{array}$ & $\begin{array}{l}0,289 \\
0,005\end{array}$ & $\begin{array}{l}1,323 \\
0,034\end{array}$ & $\begin{array}{l}0,093^{*} \\
0,487^{\text {ns }}\end{array}$ \\
\hline 5. & $\begin{array}{c}\text { (Y2) } \\
\text { Motivasi }\end{array}$ & Y3 Pengambilan keputusan & $\theta 2$ & 0,141 & 1,428 & $0,077^{*}$ \\
\hline
\end{tabular}

Sumber: Hasil pengolahan data, 2008

Keterangan:

* Signifikan pada taraf signifikansi $10 \%$

** Signifikan pada taraf signikansi $5 \%$

*** Signifikan pada taraf signifikansi $1 \%$

ns Tidak Signifikan 


\section{Pengaruh sosial-budaya terhadap faktor pribadi}

Hasil analisis atas pengujian pengaruh sosialbudaya terhadap faktor pribadi sebagaimana dapat dilihat pada Tabel 1 menunjukkan bahwa nilai critical ratio (CR) dihasilkan adalah $11.159>$ 2.33, nilai probability $(P)=0.000$ dan nilai Regresion weight sebesar 0.249, yang berarti bahwa pengaruhnya positif dan signifikan pada tingkat signifikansi $1 \%$. Dengan demikian, hipotesis yang menyatakan lingkungan sosial-budaya yang terdiri atas dimensi ilmu pengetahuan dan teknologi, status sosial, keyakinan, norma, nilai dan kebiasaan mempengaruhi faktor pribadi mahasiswa terbukti.

Hasil penelitian tersebut didukung pendapat Hawkins, et,al (1998) yang mengatakan bahwa setiap orang mempunyai pandangan tentang dirinya (self concept) dan mencoba hidup yang disesuaikan dengan sumberdaya yang dimilikinya (life style). Pandangan seseorang tentang dirinya dan cara dia mencoba hidup ditentukan oleh faktor-faktor internal yang terdiri dari persepsi, proses belajar, memori, motif, keperibadian dan sikap serta faktor eksternal seperti budaya, subbudaya, demografis, kelas sosial, kelompok rujukan dan aktivitas pemasaran.

Berdasarkan uraian di atas, maka hasil penelitian ini memberikan gambaran bahwa lingkungan sosial-budaya mempengaruhi faktor pribadi mahasiswa, dengan kata lain bahwa perkembangan ilmu pengetahuan dan teknologi, status sosial, norma, nilai-nilai dan kebiasaan yang dianut merupakan faktor yang berkonstribusi terhadap faktor pribadi mahasiswa, khususnya dalam memilih program studi di perguruan tinggi.

\section{Pengaruh sosial-budaya terhadap motivasi}

Hasil analisis atas pengujian pengaruh sosialbudaya terhadap motivasi mahasiswa seperti yang nampak pada Tabel 1 menunjukkan bahwa nilai critical ratio (CR) dihasilkan adalah $2.411>$ 2.33 , nilai probability $(P)=0.008$ dan nilai Regresion weight sebesar 0.254. Ini berarti bahwa lingkungan sosial-budaya berpengaruh secara positif dan signifikan terhadap motivasi mahasiswa pada tingkat signifikansi $1 \%$. Dengan demikian, hipotesis yang menyatakan variabel sosial-budaya berpengaruh positif dan signifikan terhadap motivasi diterima. Hasil penelitian ini memberikan gambaran bahwa lingkungan sosialbudaya memiliki pengaruh penting terhadap motivasi mahasiswa. Dengan kata lain, motivasi khususnya dalam memilih program studi di perguruan tinggi dipengaruhi oleh lingkungan sosial-budaya.

Hasil penelitian ini searah dengan pendapat Schfiman \& Kanuk (2007), yang mengatakan bahwa kebutuhan merupakan akibat dari keadaan psikologis subjektif individu dari berbagai hubungan dengan orang lain. Ini menunjukkkan bahwa munculnya kebutuhan selain dipengaruhi oleh faktor internal individu, juga dipengaruhi faktor eksternal seperti budaya dan lingkungan sosial dimana mereka berada dan keputusan yang pada ahirnya dipilih dapat memenuhi kebutuhannya baik yang bersifat primer maupun sekunder.

Salah satu indikator yang digunakan untuk mengukur variabel lingkungan sosial-budaya adalah relevansi program studi dengan perkembangan ilmu pengetahun dan teknologi ternyata memiliki nilai rata-rata cukup tinggi. Hal tersebut memberikan indikasi bahwa salah satu faktor yang mendorong mahasiswa memilih program studi adalah pengaruh perkembangan ilmu pengetahuan dan teknologi. Dengan kata lain, motivasi utama mahasiswa memilih program studi yang memiliki relevansi dengan perkembangan ilmu pengetahuan dan teknologi, sebab memilih jurusan yang sesuai dengan perkembangan IPTEK dapat bermakna memilih jurusan yang memiliki prospek pekerjaan yang luas.

\section{Pengaruh sosial-budaya terhadap pengambilan keputusan}

Secara teoritis budaya merupakan penentu keinginan dan perilaku yang paling dasar (Kotler, 2005). Demikian pula pendapat Peter dan Olson (2000), yang mengatakan bahwa sebagai aspek terluas dari lingkungan sosial makro, budaya adalah faktor paling kuat dan paling berpengaruh dalam perilaku, kognisi dan afeksi konsumen.

Pendapat tersebut di atas sejalan dengan hasil penelitian ini, yang menemukan bahwa faktor sosial-budaya berpengaruh secara positif dan signifikan terhadap pengambilan keputusan. Hal tersebut dapat dilihat dari hasil analisis atas pengujian pengaruh sosial-budaya terhadap 
pengambilan keputusan seperti pada Tabel 46 menunjukkan bahwa nilai critical ratio (CR) dihasilkan adalah $1.379>1.28$, nilai probability $(P)=0.084$ dan nilai Regresion weight sebesar 0.089 , yang berarti bahwa pengaruhnya positif dan signifikan pada tingkat signifikansi $10 \%$.

Dengan demikian, hipotesis yang menyatakan sosial-budaya berpengaruh positif dan signifikan terhadap pengambilan keputusan terbukti. Hasil penelitian ini memberikan gambaran bahwa lingkungan sosial-budaya yang meliputi indikator relevansi program studi dengan perkembangan ilmu pengetahuan dan teknologi, status sosial, keyakinan, norma, kebiasaan dan nilai masyarakat berpengaruh secara berarti terhadap pengambilan keputusan mahasiswa dalam memilih program studi di Sulawesi Selatan. Hasil penelitian ini sejalan dengan hasil penelitian Childers dan Rao (1992) yang mengukur pengaruh kepuasan pembelian individu kelompok referensi berdasarkan hubungan keluarga dan rekan sebaya serta menentukan variasi pengaruh pada lintas budaya berdasarkan hubungan keluarga dalam keputusan konsumen individu. Hasil yang ditemukan adalah anggota keluarga dan kelompok referensi memberikan pengaruh yang nyata terhadap keputusan pembelian produk dan jasa yang dibeli.

Salah satu indikator sosial-budaya yang mendapat respon tertinggi dari responden adalah relevansi program studi dengan perkembangan IPTEK. Hal tersebut mengindikasikan bahwa faktor utama yang menjadi pertimbangan mahasiswa dalam memilih program studi di perguruan tinggi adalah apakah program studi tersebut memiliki prospek lapangan kerja yang cukup luas. Sebagai contoh yaitu meningkatnya minat mahasiswa untuk memilih program studi teknologi informasi (IT) disebabkan oleh karena semakin meluasnya penggunaan teknolgi informasi pada semua aspek kehidupan yang berarti pula kesempatan kerja di sektor ICT semakin terbuka secara luas.

\section{Pengaruh kelompok rujukan terhadap faktor pribadi}

Hasil analisis atas pengujian pengaruh kelompok rujukan terhadap faktor pribadi yang menunjukkan bahwa nilai critical ratio (CR) dihasilkan adalah $8.716>2.33$, nilai probability $(P)=0.000$ dan nilai
Regresion weight sebesar 0.249. Hasil tersebut membuktikan bahwa kelompok rujukan berpengaruh positif dan signifikan terhadap faktor pribadi dengan tingkat signifikansi $1 \%$.

Hasil penelitian ini memberikan gambaran bahwa kelompok rujukan yang terdiri dari orang tua, teman, guru, pengaruh orang sukses serta beberapa kelompok rujukan lainnya berpengaruh penting dan nyata terhadap faktor pribadi mahasiswa, khsususnya dalam proses pemilihan program studi di Sulawesi Selatan. Hasil penelitian ini sejalan dengan pendapat Peter dan Olson (2000), yang mengatakan bahwa keluarga dan kelompok-kelompok referensi dipengaruhi oleh budaya, sub-budaya dan kelas sosial dari lingkungan sosial makro dan selanjutnya mempengaruhi perilaku individu konsumen. Selanjutnya, Peter dan Oleson (2000) mengatakan salah satu tujuan seseorang memihak atau bergabung dengan sebuah kelompok referensi adalah untuk mendapatkan makna yang digunakan untuk membangun, memodifikasi atau memelihara konsep pribadi mereka (ekspresi nilai).

\section{Pengaruh kelompok rujukan terhadap motivasi}

Hasil penelitian ini menemukan bahwa kelompok rujukan berpengaruh positif dan signifikan terhadap motivasi. Hal tersebut dapat dibuktikan dari hasil analisis atas pengujian pengaruh kelompok rujukan terhadap motivasi seperti yang nampak pada tabel 46 yang menunjukkan bahwa nilai critical ratio (CR) dihasilkan adalah $3.268>2.33$, nilai probability $(\mathrm{P})=0.001$ dan nilai Regresion weight sebesar 0.197. Hasil analisis tersebut membuktikan bahwa kelompok rujukan berpengaruh positif dan signifikan terhadap motivasi pada tingkat signifikansi $1 \%$. Dengan demikian, hipotesis yang menyatakan kelompok rujukan berpengaruh positif dan signifikan terhadap motivasi diterima. Hasil penelitian ini juga memberikan gambaran bahwa kelompok rujukan memiliki konstribusi yang berarti terhadap motivasi mahasiswa, khususnya dalam memilih program studi di perguruan tinggi.

Penelitian ini sejalan dengan penelitian Burns (2006) terhadap faktor yang mempengaruhi siswa dalam memilih perguruan tinggi di Sekolah Pertanian, Makanan dan Sumberdaya Alam di 
School University of Missouri Columbia, menemukan bahwa faktor keluarga, anggota keluarga lainnya dan kelompok referen mempengaruhi motivasi mahasiswa dalam pemilihan jurusan di perguruan tinggi. Hasil penelitian dapat disimpulkan bahwa motivasi calon mahasiswa dalam memilih program studi di perguruan tinggi sangat dipengaruhi oleh Kelompok rujukan yang terdiri dari orang tua, teman, guru, rekan dalam organisasi, pendapat para ahli dan orang-orang yang telah sukses di bidang tersebut.

\section{Pengaruh kelompok rujukan terhadap pengambilan keputusan}

Hasil kajian teoritis menunjukkan bahwa kelompok rujukan yang terdiri atas orang tua, teman, guru, pakar, pemimpin opini dan kelompok rujukan lainnya memiliki pengaruh yang cukup kuat terhadap proses pengambilan keputusan, sebagaimana pendapat Walk dan Hensby (2003), Kern (2000), yang mengatakan bahwa keluarga memberikan dukungan signifikan dalam pengambilan keputusan. Sejalan dengan pendapat tersebut di atas, hasil penelitian ini menemukan bahwa kelompok rujukan memiliki pengaruh positif dan signifikan terhadap pengambilan keputusan. Hal ini dapat dilihat dari hasil analisis atas pengaruh kelompok rujukan terhadap pengambilan keputusan seperti yang nampak pada tabel menunjukkan bahwa nilai critical ratio (CR) dihasilkan adalah $1.368>$ 1.28 , nilai probability $(\mathrm{P})=0.086$ dan nilai Regresion weight sebesar 0.059 , yang berarti bahwa pengaruhnya positif dan signifikan pada tingkat signifikansi $10 \%$. Dengan demikian, hipotesis yang menyatakan kelompok rujukan berpengaruh positif dan signifikan terhadap pengambilan keputusan terbukti.

Hasil penelitian ini sesuai dengan temuan penelitian Brooks (2004), yang menyatakan bahwa $90 \%$ dari responden menyatakan telah berkonsultasi dengan orang tua tentang pilihan mereka dalam memilih perguruan tinggi. Hasil penelitian ini juga sesuai dengan hasil penelitian yang dilakukan oleh Shanka, Quintal dan Taylor (2005) yang menemukan 52\% mahasiswa memilih studi di Perth karena dipengaruhi oleh keluarga dan teman. Selanjutnya, hasil penelitian ini sesuai dengan hasil penelitian Tatar dan Oktay (2006) tentang proses pencarian dan pemilihan perguru- an tinggi di Turky, menemukan $98 \%$ mahasiswa mendapatkan sumber informasi dari buku penuntun penempatan di perguan tinggi, $74 \%$ sumber informasi dari keluarga dan anggota keluarga lainnya, 36\% bersumber darai guru pan pembimbing di sekolah, $11 \%$ darri dosen dan $10 \%$ dari staf perguruan tinggi.

\section{Pengaruh komunikasi pemasaran terhadap pengambilan keputusan}

Hasil analisis atas pengujian pengaruh komunikasi pemasaran terhadap pengambilan keputusan menunjukkan bahwa nilai critical ratio (CR) dihasilkan adalah $3.482>2.33$, nilai probability $(P)$ $=0.000$ dan nilai Regresion weight sebesar 0.043 . Hasil tersebut menunjukkan bahwa pengaruhnya positif dan signifikan pada tingkat signifikansi $1 \%$. Dengan demikian, hipotesis yang menyatakan komunikasi pemasaran berpengaruh positif dan signifikan terhadap pengambilan keputusan terbukti. Hasil penelitian ini memberikan gambaran bahwa komunikasi pemasaran yang terdiri dari iklan, promosi penjualan dan berbagai program publisitas berpengaruh penting terhadap pengambilan keputusan mahasiswa.

Hasil temuan dalam penelitian ini sejalan dengan pendapat Kotler (2005), yang menyatakan bahwa proses keputusan pembelian konsumen dipengaruhi oleh rangsangan pemasaran (marketing stimuly) yang terdiri atas produk, promosi, price dan place serta ransangan lain yang meliputi kondisi ekonomi, budaya, teknomogi dan politik. Ini menunjukkan bahwa komunikasi pemasaran (promosi) berpengaruh terhadap proses keputusan pembelian dengan cara mempengaruhi kesadaran pembeli (Buyer's conciouness).

\section{Pengaruh faktor pribadi terhadap motivasi}

Hasil analisis atas pengujian pengaruh faktor pribadi terhadap motivasi seperti yang nampak pada tabel 46, menunjukkan bahwa nilai critical ratio $(C R)$ dihasilkan adalah $1.323>1.28$, nilai probability $(P)=0.093$ dan nilai Regresion weight sebesar 0.289. Hasil analisis tersebut membuktikan bahwa konstruk faktor pribadi berpengaruh secara positif dan signifikan terhadap motivasi pada tingkat signifikansi $10 \%$. Dengan demikian, hipotesis yang menyatakan faktor pribadi 
berpengaruh positif dan signifikan terhadap motivasi terbukti. Hasil penelitian ini memberikan gambaran bahwa faktor pribadi yang terdiri dari keperibadian dan gaya hidup berpengaruh penting terhadap motivasi mahasiswa, khususnya dalam memilih program studi di perguruan tinggi.

Penelitian ini sejalan dengan pendapat Wells \& Prensky (1996) yang menyatakan bahwa aktivitas pembelian konsumen ditentukan oleh proses perilaku yang terdiri dari motivasi, persepsi, learning, formasi sikap. Proses perilaku dipengaruhi oleh latar belakang karakteristik konsumen yang terdiri dari faktor demografi, kepribadian, gaya hidup, budaya, nilai dan kelompok rujukan. Ini berarti bahwa motivasi sebagai salah satu unsur proses perilaku juga dipengaruhi oleh faktor pribadi sebagai salah satu komponen dari karakteristik konsumen.

\section{Pengaruh faktor pribadi terhadap pengambilan keputusan}

Hasil analisis atas pengujian pengaruh faktor pribadi terhadap pengambilan keputusan seperti yang nampak pada tabel menunjukkan bahwa nilai critical ratio (CR) dihasilkan adalah 0.034 , nilai probability $(\mathrm{P})=0.487$ dan nilai Regresion weight sebesar 0.005 , yang berarti tidak memenuhi nilai ketentuan dan syarat yang ditetapkan dalam penelitian ini, baik pada taraf signifikansi $10 \%, 5 \%$ maupun $1 \%$. Dengan demikian, hipotesis yang menyatakan faktor pribadi berpengaruh positif dan signifikan terhadap pengambilan keputusan tidak terbukti. Hasil penelitian ini menunjukkan bahwa faktor pribadi tidak berpengaruh secara berarti terhadap pengambilan keputusan mahasiswa dalam memilih program studi di Sulawesi Selatan.

Temuan dalam penelitian ini dapat diartikan bahwa mahasiswa dalam memilih program studi kurang mempertimbangkan minat dan kemampuan yang dimiliki dalam memilih program studi di perguruan tinggi. Hal tersebut disebabkan oleh karena sebagian besar mahasiswa dalam memilih jurusan dipengaruhi oleh kelompok rujukan, seperti orang tua, teman atau pengaruh kelompok rujukan lainnya.

\section{Pengaruh motivasi terhadap pengambilan keputusan}

Motivasi menunjukkan alasan untuk suatu perilaku dan merupakan kekuatan yang enerjik yang menggerakkan perilaku dan memberikan tujuan dan arah perilaku (Supranto, 2007). Motivasi merupakan tenaga penggerak dalam diri individu yang mendorong mereka bentindak (Schiffman dan Kanuk, 2007). Beberapa pendapat di atas membuktikan bahwa memahami kebutuhan konsumen merupakan hal yang sangat penting dan sekaligus mendukung hasil penelitian ini yang menemukan bahwa motivasi berpengaruh secara positif dan signifikan terhadap pengambilan keputusan.

Temuan tersebut dapat dibuktikan dari hasil analisis atas pengujian pengaruh motivasi terhadap pengambilan keputusan seperti yang nampak pada Tabel 4.6 dengan nilai critical ratio (CR) dihasilkan adalah $1.428>1.28$, nilai probability $(P)=0.077$ dan nilai Regresion weight sebesar 0.141 , yang berarti bahwa pengaruhnya positif dan signifikan pada tingkat signifikansi $10 \%$. Dengan demikian, hipotesis yang menyatakan motivasi berpengaruh positif dan signifikan terhadap pengambilan keputusan terbukti. Hasil penelitian ini memberikan gambaran bahwa motivasi berpengaruh secara nyata terhadap pengambilan keputusan mahasiswa dalam memilih program studi di perguruan tinggi.

Hasil penelitian ini juga searah dengan pendapat Tuggaesti (2007), menemukan bahwa terdapat pengaruh yang positif antara motivasi berbelanja terhadap kepuasan berbelanja. Demikian pula pendapat Hawkins, et, al (2004), yang mengatakan bahwa kelompok motif yang dapat dipahami oleh konsumen sebagai faktor pendorong untuk membeli disebut "manifest motives", sedangkan kelompok motif yang tidak diketahui atau disadari atau segan untuk mengakuinya disebut "laten motives".

Sebagai implikasi kebijakan dari hasil penelitian ini bahwa pengelola program studi di perguruan tinggi harus memahami secara cermat motivasi paling kuat yang mendorong calon mahasiswa untuk melanjutkan studi di perguruan tinggi. Untuk selanjutnya mengembangkan program studi yang dapat memenuhi kebutuhan mahasiswa tersebut. Dalam memahami motivasi 
calon mahasiswa dalam memilih jurusan di perguruan tinggi, pengelola program studi perlu untuk melakukan riset motivasi.

\section{Simpulan dan Saran Simpulan}

Dari pembahasan hasil penelitian, maka dapat disimpulkan sebagai berikut. Pertama, sosialbudaya berpengaruh positif dan signifikan terhadap faktor pribadi, motivasi, dan pengambilan keputusan mahasiswa dalam memilih program studi. Kedua, kelompok rujukan berpengaruh positif dan signifikan terhadap faktor pribadi, motivasi dan pengambilan keputusan mahasiswa dalam memilih program studi. Ketiga, komunikasi pemasaran berpengaruh positif dan signifikan terhadap pengambilan keputusan mahasiswa dalam memilih program studi. Keempat, faktor pribadi berpengaruh positif dan signifikan terhadap motivasi, namun tidak signifikan terhadap pengambilan keputusan mahasiswa dalam memilih program studi. Kelima, motivasi berpengaruh positif dan signifikan terhadap pengambilan keputusan mahasiswa dalam memilih program studi.

\section{Saran}

Berdasarkan atas simpulan, maka dikemukakan beberapa saran agar: 1) satuan akademik pengelola program studi, khususnya yang memiliki peminat relatif kurang melakukan terobosan manajemen pengelolaan program studi melalui pengembangan program studi sesuai dengan akselerasi perkembangan IPTEK. Di samping itu, satuan akademik pengelola program studi memberikan bekal kompetensi hard-skill maupun soft-skill untuk pemenuhan berbagai kebutuhan (motif) mahasiswa; 2) dalam upaya satuan akademik menghasilkan lulusan yang memiliki kompetensi sesuai dengan kualifikasi dan kebutuhan pasar, maka pengelola program studi perlu melakukan evaluasi dan revisi kurikulum secara periodik dan mengembangkan kurikulum berbasis kompetensi (KBK) dengan melibatkan berbagai pemangku kepentingan (stakeholder); 3) setiap pengelola program studi secara aktif dan kreatif memberikan muatan lokal pada kurikulum sebagai penunjang kompetensi utama, seperti: keterampilan ICT, Bahasa Inggris, dan keterampilan lain yang terkait dengan kompetensi inti yang diperlukan dunia kerja; 4) pengelola program studi memanfaatkan pengaruh orang tua, pendapat orang yang sukses berkarier (termasuk alumni) dan peran dosen serta anggota kelompok lainnya yang berpengaruh sebagai opinion leader maupun sebagai endorser untuk mempengaruhi motivasi, sikap/persepsi calon mahasiswa; dan 5) dalam upaya memperbaiki kualitas operasional pelayanan dan peningkatan akademik, pengelola program studi diharapkan mampu mengembangkan pelayanan prima serta penyediaan fasilitas pendidikan yang memadai untuk mendukung setiap kegiatan akademik. Selain itu, pengelola program studi mampu memberi jaminan mutu kepada semua stakeholder dengan cara melaksanakan penjaminan mutu (quality assurance), baik secara internal melalui evaluasi diri maupun penjaminan mutu eksternal (external audit) melalui akreditasi BAN PT.

\section{Pustaka Acuan}

Arambewela, Rodney, Hal, Jhon and Zuhair, Segu, 2005, Postgraduate Internasional Student from Asia : Factor Influecing Satisfaction, Journal Marketing for Heigher Education, Volume 15 Number 22005.

Babin, B.J., Darden, W.R and Griffin M, 1994, Work and/or fun : Measuring Hedonik and utilitarian shopping volue, Jorunal of Consumer Research 20, 644-656.

Brooks, R. 2004. My mum would be a pleased as punch if I actually went, but my dad seems a bit more particular about it: Paternal involvement in young people's higher education choices, British Educational Research Journal, 30(4), 495-515.

Burns, Mavuin J., 2006. Factors Influencing The College Choice Of African-American Student Resources, A Thesis presented to the Faculty of the Graduate School University of Missouri - Columbia.

Burroughs, J.E, \& Mick, D. G, 2004, Exploring antecedents and consequences of consumer creativity in a problem solving context, Journal of Consumer Research, 31 402-411. 
Childers, T.L, and Akshay, R. R, 1992, The influence of Family and peer based reference group on Consumer Decision, Journal of Consumer Research, Vol. 19, 189-211

Direktorat Jenderal Pendidikan Tinggi-Dipediknas, 2004, Strategi Pendidikan Tinggi Jangka Panjang 2003-2010, mewujudkan perguruan tinggi yang berkualitas (HELTS 2003-2010).

Engle, James F, Blackwell, Rogre D And Miniard, Paul W., 1995. Perilaku Konsumen, Jilid-1, Binaputra Aksara, Jakarta.

Gulsha. Jahida and Paul, Anindita, 2006, Factors Influncing Students Choosing Private Universities In Bangladesh Departemen Of Economics East Wet University, Dhaka, Bangladesh.

Habibi, B. J, 2004, Beberapa Pemikiran Tentang Peran Sumberdaya Manusia Dalam Membangun Masa Depan Bangsa, Makalah disampaikan dihadapan Guru besar, Dosen Mahasiswa UGM.

Hawkins, Del I., Roger J., Best dan kenneth A., Coney, 1998. Consumber Hehavior, USA : Irwin McGrawHill.

Jim, byoungho dan Jai OK, Kim, 2001, Discount Store retailing in Korea : Shopping exitement, shopping motives and store attributes, Jorunal of Global Marketing, Vol. 15, No. 2

Kern, C. 2000. College choice influences: Urban high school students respond, Community College Journal of Research and Practice, 24,487-494

Kotler, Philip, 2005, Marketing Management, Analysis, Planning, Implementation and Control, Sixth Edition, Prenctice-Hall International, Inc., : New Jersey.

Malhotra, Naresh, K., 1993, Marketing Research An Applied Orientation. Prentice-Hall International, Inc., New Jersey.

Mangkunegara, Anwar P, 2005, Perilaku Konsumen, Edisi Revisi, Refika Aditama, Bandung.

Monga, Alokparna, Basu and John, Deborah, Roede, 2007. Differences In Brand Extension Evaluation : The Influence of Analytic Versus Holistic Thingking, JOURNAL OF CONSUMBER RESEARCH, Inc. Vol. 33 March.

Murphy. 1981, Consumber Buying Roles In Colleg Choice : Parents' and Perceptions Journal Of Marketing For Higher Education, 13 : 101-125

Nandika, Dodi., 2006. Universitas, Riset dan Daya Saing Bangsa. Pustaka Pelajar : Jakarta.

Nazir, Moh. 2005, Metode Penelitian, Ghalia Indonesia, Bogor.

Peter J, Paul dan Olson, Jerry G., 2000. Perilaku Konsumen dan Strategi Pemasaran, Jillid-1, ediri keempat, Erlangga, Jakarta.

Peraturan Pemerintah Republik Indonesia Nomor 60 Tahun 1999 Tentang Pendidikan Tinggi.

Prasetijo, Ristiyanti dan Ihalauw, John J.O.I, 2005, Perilaku Konsumen, Andi Offset, Yogyakarta.

Rahayu, Sri, 2005, SPSS Versi 12,0 Dalam Riset Pemasaran, Alfabeta : Bandung.

Sekaran, I, J, 2003, Research Method for Businner : A Skill Building Approach, 3nd end, New Yorlk : John Wiley \& Soon.

Schuler, Randall S dan Jackson Susan E, 1990 Manajemen Sumberdaya Manusia: Menghadapi abad ke-21, jilid-1, Erlangga jakarta

Stanton, William J., 1991, Fundamental of Marketing, $9^{\text {th }}$ ed, McGraw-Hill, Inc., : United States of America.

Shanka, Tekle, Quintal, Vanessa, Taylor, Ruth, 2005, Factors influencing International Students'Choice of an Education Destination -a Analysis, Journal of Marketing for Higher Education, vol 15 (2)

Shiffman, Leon G and Kanuk, Leslie, Laser, 2007, Perilaku Konsumen, Edisi ketujuh, Indeks, Jakarta.

Sheth, J.N., and B. Mittal, 2004, Consumer Behavior : A Managerial Perspective, Mason, Ohio : SouthWester.

Smith, K., \& Bers, T.H., 1989. Parents and the college choice decisions of community college students, College an University, 64 (4) 355-348.

Supranto, J., 2007. Perilaku Konsumen dan Strategi Pemasaran: Untuk memenangkan persaingan bisnis, Mitra Wacana Media, Jakarta. 
Tatar, Erdal and Oktay, Munir, 2006. Search, Choice And Presistence For Higher Education : A Case Study In Turkey, Eurasia Journal Of Mathematics, Sciensce and Technology Education Volume 2, Number 2, July 2006

Tuggaesti, Dea, 2007. Pengaruh Motivasi belanja \& atribut toko pada kepuasaan pelanggaran matahari supermarket, Tesis Program Studi Magister Manajemen, UGM, Yogyakata.

Undang Undang Nomor 20 Tahun 2003 Tentang Sistem Pendidikan Nasional.

Walck, D. \& Hensby, S., 2003. Career and Degree choice at transition to university. Australian Journal Of Career Development, 12 (3), 64-71.

Wells, Willaam D and Presnky, David, 1996, Consumber Behavior, John Wiley \& Sons, Inc, New York. 